\title{
Consideraciones finales: historia, literatura, identidad narrativa, memoria. Una reflexión desde Argentina
}

Entre 1970-1980, con la oleada de regímenes dictatoriales $y$ neoconservadores que asolaron los países del continente latinoamericano y a su vez generaron uno de los mayores procesos de exilios político-culturales, la ficción literaria inició una profunda y novedosa revisión e indagación crítica de la historia y los discursos historiográficos que, entre otras cosas, podía permitir explicar y comprender los presentes de crisis de aquellos países y sociedades. Por supuesto, en la evolución literaria de cada país y de Argentina, desde donde realizamos estas consideraciones, aquella revisión de lo histórico desde la ficción no era inédita. Pero a partir de ese momento la novela histórica adquirió una nueva importancia, diversidad e interesante densidad en su corpus. En el conjunto de géneros que integran la "ficción histórica", se perfilan dos líneas persistentes con indudables variaciones, hasta el presente argentino: una novela histórica más experimental y otra más tradicional, que trabaja según las convenciones narrativas heredadas de la gran novelística histórica del siglo XIX. Teniendo en cuenta este marco, repensaremos una serie de cuestiones vinculadas a la "ficción histórica", pero más emparentadas con la vertiente experimental, donde la representación y los problemas de la escritura y del lenguaje devienen centrales. $Y$ si bien a efectos de anclar nuestras reflexiones tomamos casos de la literatura argentina contemporánea, estas consideraciones quedan abiertas para ser repensadas en el marco más amplio que propone el presente número de la Revista Canadiense de Estudios Hispánicos, el de las literaturas de habla hispana de uno y otro lado del Atlántico.

CONSIDERACIONES ACERCA DE LO HISTÓRICO Y LO LITERARIO

Entre 1970-1980, con la oleada de regímenes dictatoriales y neoconservadores que asolaron los países del continente latinoamericano y a su vez generaron uno de los mayores procesos de exilios políticoculturales, la ficción literaria inició una profunda y novedosa revisión e indagación crítica de la historia y los discursos historiográficos que, entre otras cosas, podía permitir explicar y comprender los presentes de crisis de aquellos países y sociedades. Por supuesto, en la evolución literaria de 
cada país y de Argentina, desde donde realizamos estas consideraciones, aquella revisión de lo histórico desde la ficción no era inédita. Pero a partir de ese momento la novela histórica adquirió una nueva importancia, diversidad e interesante densidad en su corpus. Asimismo, los diversos aspectos vinculados a la compleja cuestión de las memorias, individuales y sociales, también adquirieron persistente importancia en la literatura de habla hispana, en particular desde entonces y en la trama histórica de dichos regímenes represivos, las resistencias a los mismos y los consecuentes procesos que se reformularon desde ese momento.

Aquel momento histórico de los 70 y 80, con sus efectos prolongados incluso hasta el presente, hizo revisar aquellas amplias cuestiones en el desarrollo de nuestras literaturas, como por ejemplo lo referente a las interacciones matizadas entre ficción e historia y lo vinculado al tema de las memorias. Hablando de modo específico de la literatura argentina, desde aquella coyuntura se redefinieron de manera notable las relaciones entre ficción e historia, entre literatura y memoria. Esto llevó a apreciar de otra manera estos vínculos hasta la actualidad y revisar sus genealogías en los diferentes tiempos y espacios histórico-literarios antes del periodo mencionado.

A lo largo de las últimas décadas se han elaborado una diversidad de aspectos teóricos, políticos y literarios, que se plantean en este texto. La formulación que encabeza nuestra reflexión, "Historia, literatura, identidad narrativa, memoria", pone de relieve, en primer término, los vínculos entre lo literario y lo histórico, así como la compleja madeja de cuestiones teóricas y críticas en ellos implicada, por ejemplo, la cuestión de la mímesis: las posibilidades de representación del pasado, o el problema de las huellas de lo pretérito y sus reconstrucciones discursivas. Estrechamente relacionado con ello, está también el problema de las temporalidades y espacialidades involucradas en aquella textualización de lo pretérito. Y de aquí surgen otras cuestiones - lo referencial, la importancia del relato, la tramas histórico-narrativas y sus similitudes y diferencias - conectadas con esa constelación de problemáticas incluidas en la denominación "ficción histórica".

Así, para anclar lo señalado y referenciando en el periodo tomado aquí como punto de inflexión, basta pensar en la relevancia cuantitativa y cualitativa que adquiere la narrativa histórica. En el devenir de la literatura y cultura argentinas durante el periodo dictatorial de 1976-1983 y en los años siguientes, aparecen novelas como Cuerpo a cuerpo (1979) de David Viñas, Juanamanuela mucha mujer (1980) de Martha Mercader, Respiración artificial (1980) de Ricardo Piglia, Río de las congojas (1981) de Libertad Demitrópulos, El entenado (1983) de Juan José Saer, Los perros del paraíso 
(1983) de Abel Posse, Ansay o los infortunios de la gloria (1984) de Martín Caparrós, En esta dulce tierra (1984) y La revolución es un sueño eterno (1987) de Andrés Rivera y La novela de Perón (1985) de Tomás Eloy Martínez, entre muchas otras, hasta llegar a obras ya de la década siguiente como La amante del Restaurador (1993) de María Esther de Miguel o registrarse una recurrencia de este tipo de narrativa hasta el presente, conjunto de obras que igualmente manifiestan la diversidad de aquella modalidad narrativa (Ludmer 44-54; Lojo "Novela"). Porque si bien en toda la narrativa histórica la cuestión de las representaciones del pasado es central, algunos de los elementos que diferencian a cada una de las obras como las antes enumeradas son, por un lado, cómo los textos trazan los pasajes posibles entre el pasado reconstruido y el presente de enunciación implicado en aquello. Otro elemento es la relevancia que las cuestiones de la escritura y el lenguaje adquiere en relación con la representación posible del pasado, y los acercamientos que los sujetos construyen con aquel pretérito. Es la considerable distancia que hay entre El entenado o $\mathrm{La}$ revolución es un sueño eterno y La amante del Restaurador, todas novelas históricas pero que, en los dos primeros casos, problematizan el proceso de escritura, el lenguaje y las formas de reconstrucción del pasado. En tanto que la última es una lograda realización convencional del género (sin por esto desconocerse su base documental y su afirmativa pretensión de cierta "veracidad histórica").

Ya a partir de los 70 y 8o, en el conjunto de géneros que integran la "ficción histórica", se perfilan dos líneas persistentes con indudables variaciones, hasta el presente argentino: una novela histórica más experimental y otra más tradicional, que trabaja según las convenciones narrativas heredadas de la gran novelística histórica del siglo XIX. Teniendo en cuenta este marco, repensaremos una serie de cuestiones vinculadas a la "ficción histórica", pero más emparentadas con la vertiente experimental, donde la representación y los problemas de la escritura y del lenguaje devienen centrales. Y si bien, a efectos de anclar nuestras reflexiones, tomamos casos de la literatura argentina contemporánea, estas consideraciones quedan abiertas para ser repensadas en el marco más amplio que propone el presente número de la Revista Canadiense de Estudios Hispánicos, el de las literaturas de habla hispana de uno y otro lado del Atlántico.

FICCIÓN Y VERDAD HISTÓRICA

Sabemos que uno de los rasgos más visibles de la ficción moderna es que no necesariamente se define en relación a la búsqueda de la verdad. Algunos géneros, como el fantástico, vuelven problemático - y por 
momentos irrelevante - pensar este vínculo. Pero esto no ha ocurrido así, a lo largo de su desarrollo, con los géneros narrativos realistas y, dentro de esta esfera, con las diversas líneas de narrativa histórica. Al estar en juego la reconstrucción del pasado, asimismo está en disputa la construcción más próxima a la verdad acerca de dicho pasado. Pero esto, a su vez, se relaciona, por un lado, con los cambios de paradigmas filosóficos, culturales y científicos dominantes acerca de posibles conocimientos verdaderos. Por otra parte, se enlaza con las transformaciones históricas del espacio literario, y las correlativas concepciones cambiantes de lo ficcional y lo no ficcional. Esto se aprecia en el desarrollo que va desde la novela histórica canónica - en particular la del siglo XIX - hasta la contemporánea, con sus múltiples variantes. A su vez, nunca existe una única concepción filosófica, cultural y científica en cada coyuntura, sino que coexisten varias, con alguna predominante. Por ejemplo, durante el siglo XIX convivieron tanto variedades de novela o ficción histórica romántica como positivista cuyas genealogías siguen incidiendo en las renovaciones del género.

Desde mediados del siglo XIX, el problema de la verdad histórica no ha dejado de ser relevante. Pero se modificó la perspectiva sobre la constitución del conocimiento verdadero, reconociendo y subrayando el relativismo de dicha construcción y la importancia de la perspectiva subjetiva sobre la verdad, junto con el carácter intersubjetivo de la misma. En la narrativa argentina del siglo XX y XXI, algunas poéticas han trabajado de manera central la materia histórica - pensemos en una parte de la ficción de David Viñas, o en la de Andrés Rivera - y no han negado la postulación del develamiento de una verdad partiendo de la base de que esta es una construcción de cada sector en pugna en la vida política e ideológica de la sociedad (por ejemplo, en La revolución es un sueño eterno de Rivera, se trata de determinar cuáles eran los alcances de las ideas jacobinistas de Juan José Castelli y una parte de los revolucionarios de Mayo). En el caso de este tipo de ficciones, también al menos una mínima base documental - a veces en realidad una gran base documental - sirve de soporte a su construcción ficcional. Por cierto, aquí entran en juego las concepciones diversas y cambiantes de lo ficticio y sus alcances. Para algunas de estas, el problema de la verdad histórica no resulta relevante, aunque sí, en efecto, lo es para todo tipo de narrativa histórica, inclusive para aquella que trabaja tangencialmente, transgrediéndolas, con las leyes del género, como es el caso de la variante experimental de la novela histórica actual. En este sentido, la transformación de materiales históricos, al ser puestos en relato y de modo frecuente con una alta ironía, se produjo inevitablemente, desde siempre, aún cuando se buscara una 
supuesta reconstrucción lo más fidedigna y lineal posible. No obstante, esto también se volvió explícito y central, cuando las concepciones historiográficas se modificaron de modo radical. Ocurrió sobre todo a partir del momento en que la denominada nueva historiografía puso en escena la postulación teórica central de que el discurso historiográfico, sea cual sea el paradigma que lo legitime en términos científicos, se organiza como un relato, como una narración (Lojo "Novela"; White 13-50). Lo cual llevó a replantear las maneras de encarar el discurso historiográfico, pero a la vez revalorizó la importancia de la literatura y sus cruces entre narración e historia, al trabajar, a lo largo del desarrollo discursivo, con la múltiple variedad de elementos que entran en juego al interactuar historia, tiempo, espacio y narración. En el marco de la nueva narrativa histórica o "novela histórica contemporánea", se agudizan otras cuestiones: por ejemplo, con qué lenguajes se incorpora lo referencial histórico al relato, o quiénes escriben - y desde dónde - la historia.

Además, son fundamentales la temporalidad y los espacios diversos donde acontece la historia, cuando son abordados por el relato. La narrativa les otorga plasticidad al contarlo, al darle complejidad y riqueza de trama. Ahora bien, por otra parte, y sin pensarlo necesariamente desde la narrativa histórica, los cuestionamientos acerca de la temporalidad y espacialidad donde ocurre el devenir humano han sido una empresa central de las narrativas de vanguardias, decididamente desde principios del siglo XX. Siempre hubo antecedentes en este sentido, en particular por parte de las estéticas narrativas que han buscado, en diferentes periodos, cuestionar las narrativas realistas. Lo interesante, y por momentos fascinante, de algunos logros de la nueva narrativa histórica, es que con ella se ha renovado un género, heredero de las narrativas históricas realista y de cuño romántico, incorporando a la vez las innovaciones artísticas y problematizaciones del lenguaje que provienen de estéticas y epistemologías antirrealistas.

Por esto, en el ámbito latinoamericano de mediados de los 70 - como ocurre en la magistral Yo el Supremo (1974) de Augusto Roa Bastos o en la posterior Noticias del Imperio (1987) de Fernando del Paso - se reconstruye la historia desde los lenguajes de diversos tiempos y espacios donde actúan sus protagonistas y se registran los acontecimientos que definen sus fábulas y tramas, pero para acentuar la plasticidad y relativismo de los tiempos y espacios evocados se trabaja a la vez con el montaje y el collage escritural y lingüístico. En la literatura argentina contemporánea del mismo periodo igualmente podríamos ver cómo son elaborados los múltiples tiempos y espacios involucrados en los materiales históricos presentados en algunas narraciones. Insistimos aquí en que no 
ponemos énfasis en la narrativa histórica contemporánea de corte más tradicional, aunque no desconozcamos que inclusive en esta suele existir un tratamiento novedoso. Recordemos, por caso, el "Apéndice" deliberadamente anacrónico que Andrés Rivera agrega al final de la historia de Juan José Castelli en La revolución es un sueño eterno. Dicha historia no ha sido reconstruida desde una perspectiva de tercera persona, ajena al protagonista Castelli, sino que ha sido contada por la ficticia disposición de los dos "Cuadernos" que dejó escritos el protagonista, "el orador de la Revolución" (Rivera 13).

Paul Ricoeur señala respecto al tiempo histórico:

- La operación historiográfica procede de una doble reducción: la de la experiencia viva de la memoria y la de la especulación multimilenaria sobre el orden del tiempo.

- El estructuralismo que fascinó a varias generaciones de historiadores es propio de una instancia teórica que, por su lado especulativo, se sitúa en la prolongación de las grandes cronosofías teológicas y filosóficas, a la manera de una cronosofía científica, incluso cientificista.

- El conocimiento histórico quizá no terminó nunca con estas visiones del tiempo histórico, cuando habla de tiempo cíclico o lineal, de tiempo estacionario, de declive o de progreso. ¿No sería, pues, tarea de la memoria instruida por la historia preservar la huella de esta historia especulativa multisecular e integrarla en su universo simbólico? Sería el destino más alto de la memoria, no ya antes, sino después de la historia. (Memoria 208)

La narrativa histórica incorpora, reflexiona e integra en tensión irónica esas diversas temporalidades - con las espacialidades que le son correlativas - a las que Ricoeur alude, llegando incluso a incluirlas a todas en su "universo simbólico". Da cuenta de esas múltiples temporalidades y espacialidades, tanto en la profundidad de sus secuencialidades (diacronía) como de sus simultaneidades (sincronía), así como de las diversas visiones del tiempo enumeradas en la cita (cíclico o lineal, estacionario, en declive o en progreso). Algunos de estos elementos y la manera en que se combinan o son articulados en una narración, contribuyen a la densidad con la cual el material histórico es tratado por el relato, por el lenguaje, por la escritura. Por lo señalado, el tratamiento discursivo ha resultado importante, por una parte, en la historiografía, en los modos de relatar la reconstrucción histórica, y por otro lado, en la ficción histórica tradicional, acentuándose aún más en la narrativa histórica contemporánea.

María Cristina Pons escribe: 
En lo que a la novela histórica respecta habría que distinguir que el concepto de Historia se refiere, por un lado, al devenir histórico que la novela pretende reconstruir (es decir, el referente histórico en cuanto a hechos, tendencias histórico-sociales o personajes históricos que se asume que ocurrieron o existieron), y por otro, a la Historia como construcción discursiva (es decir, la Historia documentada, contenida en documentos o en el discurso de la historiografía).

Estas observaciones nos llevan a considerar tres aspectos importantes de la novela histórica en su relación con el material histórico: a) el carácter del pasado histórico, b) la preeminencia de este pasado histórico en el mundo ficticio, y c) la relación de la novela histórica con el documento y la historia como construcción discursiva. (56)

En los tres aspectos apuntados por Pons, resulta patente la preocupación de la novela histórica por la "verdad histórica". Esta es relevante tanto en lo individual como en lo social, tanto en lo personal como en lo colectivo, si bien pueden ser "verdades" ocultadas por mucho tiempo, o que pertenecen a las perspectivas o genealogías de los vencidos. Vinculado a aquello, Pons - dialogando sobre todo con Noé Jitrik - destaca que existen los siguientes tipos de novelas, dependiendo estos del nexo entre "la distancia temporal entre el presente del novelista y el pasado al cual se refiere". Citamos a Pons:

Jitrik distingue ... la novela histórica "catártica", porque responde a necesidades de solucionar problemas bastante inmediatos de la relación entre el presente y el pasado referido ... En el otro extremo estaría la novela histórica "arqueológica" ... En la novela histórica arqueológica, observa Jitrik, se puede objetivar la toma de posición frente a lo que se está narrando, y se la define como "un intento estético de hacerse cargo de un contexto referencial desde los medios de que se dispone en un momento muy diferente" ... Un tipo intermedio sería lo que Jitrik denomina novela histórica funcional, en la que ya no se trataría de perseguir un objetivo individual ni una recuperación arqueológica, sino que su finalidad se vincula a "una necesidad global de extender un conocimiento que se supone incompleto o deficiente en el orden intelectual". Los ejemplos que ofrece Jitrik de este tipo funcional de novela histórica son Yo el Supremo de Roa Bastos ... en las que se hace manifiesto un intento de analizar, de resolver o de acercarse a algún punto oscuro o a una laguna de la Historia. (53)

Así vemos que cada tipo de novela histórica, según algunos de los elementos descritos, definen diferentes maneras de repensar, de reubicar 
textual y referencialmente los vínculos entre verdad histórica y ficción, como componentes capitales.

ENTRE LOS GÉNEROS DE LA HISTORIA Y LOS GÉNEROS DE LA MEMORIA Existe una serie de géneros que suelen vincularse con la narrativa histórica, en particular con la novela entendida como un complejo género o pluriforma de géneros, estilos y retóricas, donde puede confluir una diversidad de discursos. Señalamos lo de pluriforma para marcar que, desde nuestro punto de vista, posiblemente sea en muchas ocasiones una combinación plural de géneros y lenguajes, una pluriforma. En la novela histórica pueden confluir muchos géneros discursivos y literarios de carácter histórico central. Muchas veces, la misma historiografía, o inclusive la filosofía de la historia, son reelaborados novelísticamente. Es lo que ocurre en Respiración artificial, cuando a lo largo del texto se insiste en la importancia de la "mirada histórica" postulada por el personaje Marcelo Maggi, y esto a la vez se articula con los múltiples fragmentos históricos que son aludidos, desde diferentes personajes y momentos, y que apuntan a demostrar que, aunque es relevante la mirada artística y literaria emblematizada en el personaje de Emilio Renzi -, jamás se debería prescindir del mirar histórico para comprender, precisamente, cada presente, cada instante por más atroz que este parezca. ${ }^{1}$ Este ejemplo, entre otros, muestra el deliberado uso e interrogación de los discursos metahistoriográficos y documentales, potenciados por el trabajo de ambiguación crítica y reflexiva por efecto del lenguaje y la ficción.

La novela de Piglia, como muchas otras de la literatura argentina y de habla hispana contemporáneas, puede ser revisada como un muestrario de algunos de los principales géneros narrativos históricos - además de los ya citados del género historiográfico y de la filosofía de la historia. Por ejemplo, la reconstrucción de los personajes y sus acciones es fundamental para apreciar la historicidad desde la ficción. Situadas en tiempos y espacios muy diferentes a los contemporáneos, reconfiguran tanto el tiempo ficcional como el histórico. Las conversaciones de Enrique Ossorio en aquella novela de Piglia, los registros escriturales como si fueran del mismo Juan José Castelli en La revolución es un sueño eterno de Rivera, o el montaje de diferentes discursos de personajes en Río de las congojas de Demitrópulos, pretenden acercarnos, con plasticidad de lenguaje e imágenes, a esos otros tiempos y espacios pretéritos reconstruidos. ${ }^{2} \mathrm{La}$ novela histórica realiza un esfuerzo extremo, en el plano de la narrativa: evocar, reconstruir las representaciones en imágenes y en palabras de las más diversas y distantes preteridades.

En otras novelas argentinas de la actualidad, esa plasticidad que otor- 
ga densidad al pasado histórico se consigue mediante una interacción constante de diferentes momentos y escenas que reúnen el pasado con la actualidad - en este sentido María Teresa Andruetto subraya que el trabajo con las "escenas", tanto en la narrativa histórica como en la narrativa de memoria es clave ("Escena"). En La novela de Perón de Tomás Eloy Martínez, las escenas centrales del regreso de Perón a Argentina en 1973, narradas desde las perspectivas de diversos protagonistas, permiten a su vez que se reconstruyan otros posibles momentos menos conocidos, menos públicos, del protagonista central. La densidad, la plasticidad, el detallismo cualitativo de la espacialidad y la temporalidad históricas que reconstruye el discurso, resultan cruciales en la mímesis de la novela histórica y de la ficción histórica en general. A ello hay que agregar otros instrumentos igualmente relevantes que llevan, al incorporarse a la pluriforma novelesca, a que lo histórico se integre más efectivamente al lenguaje. Nos referimos al testimonio, la memoria, el archivo y la prueba documental (Ricoeur, Memoria 173-236). Estos resultan elementos claves para dotar de verosimilitud histórica a la ficción. A su vez, son formas cuya presencia en la novela pone en primer plano, a veces de manera solapada y otras con particular intensidad lingüística, el problema de la escritura y del lenguaje históricos. Por ejemplo, aquello que narra el protagonista de $E l$ entenado de Juan José Saer - su estancia por diez años en una tribu de indios de ritos antropofágicos de la ribera del río Paraná cuando aún ese territorio no había sido conquistado por los españoles durante el siglo XVI - solo puede resultar creíble al ser reconstruido por él mismo en su vejez. De esta manera el entenado pretende dejar su testimonio, ya que aquellos indios lo habían dejado con vida solo a él para otorgarle el papel de "testigo" extranjero de aquella cultura (de aquí que en inglés esta novela se haya traducido muy pertinentemente con el título The Witness, como ha advertido María Cristina Pons).

En una novela casi coetánea a El entenado, Los pichiciegos (1982, 1983), no se pretende abordar un acontecimiento del pasado remoto, sino de la historia contemporánea ocurrido cuando aún gobernaba la última dictadura militar en Argentina: la Guerra de Malvinas de 1982. En la novela aparece un uso ficcional del efecto del género testimonial: en su segunda parte, notamos que hay un entrevistador que conversa con Quiquito, que posiblemente sea el único testigo sobreviviente de lo que ha sido el grupo de los "pichis", aquellos jóvenes conscriptos argentinos que, refugiados en una cueva, desertaron de las tropas militares argentinas ante una guerra que consideran absurda (Fogwill 228-230). Lo señalado arriba apunta a demostrar cómo, en la interacción de géneros históricos y ficcionales, podemos apreciar dos líneas de interés. Por un lado, que aquellos géneros 
más apegados a la "verdad histórica" pueden enriquecerse en su interacción con los procedimientos y el trabajo ficcional. Por otra parte que, a su vez, en la historia literaria y discursiva - y aquí pensamos no solamente en la literatura argentina sino también en la literatura latinoamericana - dichos géneros han tratado de disimular el efecto ficcional para lograr una mayor eficacia en la presentación de la "verdad" histórica. Esto ha sucedido, como afirma Piglia, en la historia literaria pero también en la historia política o socio-cultural contemporánea, con géneros como el relato testimonial o la no-ficción (Tres 28-30).

Hoy podemos leer el conjunto de relatos testimoniales o no ficciones de Rodolfo Walsh - desde Operación masacre (1956) hasta ¿Quién mató a Rosendo? (1968) -como novelas históricas despojadas - y de modo deliberado, tal como lo buscó su autor - de casi todo componente ficcional. Además de ser principalmente relatos testimoniales que buscaban incidir en tanto denuncias jurídico-políticas, dichas narraciones eran a la vez memorias alternativas de hechos individuales y sociales traumáticos, negados por el poder político en la coyuntura. Damos este ejemplo para sugerir cercanías y diferencias entre lo que definimos como estrictos géneros de la ficción histórica y lo que constituye géneros de la memoria. Esto último se explica tomando como referencia la obra de Walsh que, si bien se interrumpe por el asesinato de su autor en 1977 por parte de la dictadura, pasa a constituir una tradición clave de la literatura argentina y latinoamericana posterior. Las no ficciones walshianas resultan un interesante modelo para repensar los géneros de la memoria.

Si bien existe una importante tradición de relatos testimoniales en América Latina antes de la década del 1970, es a partir de ese periodo, por la instauración continental de regímenes autoritarios y represivos, que los géneros de la memoria - el testimonio, la autobiografía y la crónica adquieren progresivamente nuevas funciones sociales y culturales, para contar sobre aquello que es ocultado por el poder. La siguiente caracterización de Leonor Arfuch traza un marco que explica la importancia que los géneros de la memoria han adquirido en la Argentina contemporánea - y en otros países de habla hispana que han experimentado circunstancias históricas y culturales similares:

Ese largo camino del decir ha caracterizado las últimas décadas en Argentina, donde las narrativas testimoniales y autobiográficas han sido esenciales para la elaboración de la experiencia de la última dictadura militar. En la primera etapa, luego del retorno a la democracia en 1983, fueron netamente testimoniales: la emergencia del horror en las voces de víctimas, sobrevivientes, familiares, testigos y hasta represores, convocadas por una comisión de notables, la Comisión Nacional 
sobre la Desaparición de Personas (CONADEP), que luego se transformaron en pruebas para la justicia. En un segundo momento, se sumó la memoria de la militancia de los años setenta, que recuperaba la dimensión de lo político, su apuesta por un cambio radical, ya sea en la actividad de los movimientos de base como en la de los grupos guerrilleros que operaban en la clandestinidad. Fueron así surgiendo otras memorias, donde ambas figuras, el militante y la víctima, a menudo sin neta distinción - o tomados en su devenir, entre ascenso y "caída" -, aparecían en historias entramadas con hechos y personajes "reales" o apenas ficcionalizados, según diversos géneros y modalidades: entrevistas, biografías, autoficciones, novelas con pretensión autobiográfica, confesiones, relatos de ficción con marcas inequívocas de la experiencia. (78)

En general, los géneros de la memoria guardan estrechas similitudes con la ficción histórica, con la novela histórica. Comparten la importancia de la narración para reconfigurar identidades y otredades. En otras palabras, en ambas esferas de géneros testimoniales y literarios, cumple un rol crucial la constitución de "identidades narrativas" (Ricoeur, Historia 215-230).

LAS HUELLAS Y LAS MEMORIAS

Si bien hay una narrativa de las memorias y posmemorias, esto no implica necesariamente que sean históricas. Sin embargo, de las tipologías antes aportadas por Jitrik y citadas por Pons, la novela histórica funcional y sobre todo la catártica se acercan o asimilan a la narrativa de memoria. Igualmente, los géneros testimoniales sin pretensión literaria - memorias, entrevistas y autobiografías - pueden interactuar discursivamente con los géneros ficcionales, asimilar sus procedimientos, pero evitan, por ejemplo, el despliegue de imaginación, que en la novela histórica acompaña las representaciones del pasado. Aún así, por cierto, los géneros testimoniales han incidido e inciden de manera profunda en la transformación del espacio literario argentino contemporáneo. Esto ocurre con los usos, apropiaciones y reelaboraciones del Nunca más. Informe de la Comisión Nacional sobre la Desaparición de Personas, obra testimonial y jurídica trágicamente plural que, de esta manera, también constituyen parte del corpus literario argentino. Por ejemplo, en Desaparecido. Memorias de un cautiverio. Club Atlético. El Banco. El Olimpo. Pozo de Quilmes y ESMA (2011), el testimonio del sobreviviente Mario Villani pudo ser contado con la coautoría del crítico Fernando Reati.

Cabe ahora destacar que existe una diferencia fundamental entre la novela histórica y las narrativas de memoria. En estas últimas, hay un pasado que no termina de ocurrir, que está incidiendo activamente como herencia en el presente y que es, además, un pretérito aún marcadamente 
abierto, con respecto al cual el posicionamiento de cada sujeto está en juego. Gina Saraceni señala, por ello, la directa vinculación que tiene la memoria con la herencia, y la importancia de la lengua, crucial en ese gesto de mirar hacia atrás que, según la autora, define todo acto de rememoración:

Si la reflexión sobre la memoria como herencia revela la deuda que los vivos tienen con los muertos y la necesidad de ser responsables del "pasado que no termina de pasar", también señala los defectos y los ruidos de transmisión ... es decir, el hecho de que no siempre es posible transmitir un legado y que la transmisión revela zonas de la memoria que no se pueden representar o decir - traumas, secretos, pérdidas, rupturas, sufrimientos -, que se transmiten de manera desviada y opaca, o que no se transmiten por el exceso de real que los constituyen o por alguna estrategia política o de otro grupo que impide la transmisión o el recuerdo. (20; énfasis en el original)

Ocurre que, si bien "la memoria es un paso obligado hacia la historia" (Arfuch 77), es todavía un ámbito de "construcción de sentido" (Feierstein 53) pendiente, que implica las memorias de corto y largo plazo, lo consciente e inconsciente, lo individual y lo social. Reiteramos que el trabajo de elaboración de la memoria intenta resolver un trauma del pasado, y en este sentido es una reconstrucción inicialmente subjetiva de la verdad que, desde la experiencia individual, procura articular dicha rememoración y la memoria colectiva, social. De esta manera, coincidimos con Saraceni, quien afirma que:

En este sentido, resulta indispensable detenerse en la forma en cómo se enuncia la memoria, en su carácter narrativo, tomar en cuenta la mediación de la lengua en la articulación del pasado porque es allí, en los silencios y en los olvidos, en los saltos y balbuceos del relato donde es posible reconocer y elaborar otras versiones del pasado. (20)

Por esto un momento traumático de la historia y la cultura argentina, como fue la dictadura cívico-militar de 1976-83, implica aún vastas elaboraciones memorísticas pendientes. No son las únicas memorias individuales y sociales de dicha sociedad y cultura por cierto, pero al estar determinadas por vastos hechos traumáticos originados por un genocidio (Feierstein), una catástrofe cultural del sentido (Gatti) o una masacre social organizada (Vezzetti), todavía no han terminado de elaborarse. Dichas memorias, tensionadas hacia una reparación histórica más justa, resignifican a otras memorias de nuestra sociedad. La memoria asimismo aparece reelaborada 
en la literatura, no solo la producida por escritores de las generaciones que atravesaron y protagonizaron aquellos hechos traumáticos de la memoria colectiva, sino también por la literatura de las generaciones posteriores incluso de los nacidos con posterioridad a 1976 -, siendo todavía una cuestión y temática central de lo que se ha denominado Nueva Narrativa Argentina (Drucaroff 293-415).

Cerramos estas consideraciones sobre los cruces y matices entre novela histórica y narrativa de la memoria reflexionando sobre las obras de dos escritoras que, si bien no pertenecen a las generaciones que comienzan a publicar en los 50, 6o y 70, tampoco pertenecen a la Nueva Narrativa argentina. Nos referimos a María Teresa Andruetto y María Rosa Lojo. Ambas, además de escritoras de ficción, son ensayistas, y Lojo también es una reconocida crítica e investigadora. María Rosa Lojo se ha destacado, a lo largo de su producción artística, por un trabajo tanto del género novela histórica como de la temática y lenguajes vinculados a los géneros memorísticos, imbricados con la ficción. En su última novela, Todos éramos hijos (2015), logra una máxima tensión reflexiva entre ambas corrientes temáticas y discursivas de su obra. En esta obra, de indudable tono autoficcional por los rasgos de su protagonista - y cuyo título posee vastas resonancias, tanto míticas como actuales en la cultura argentina -, se reconstruye la historia de Frik, desde la escuela primaria y secundaria para culminar en su cursado de la Carrera de Letras en la Universidad Nacional de Buenos Aires. Esto le permite recorrer el contradictorio proceso de opciones radicalizadas - y las reacciones moderadas y conservadoras ante ello - de una parte de la juventud argentina de los años 60 y 70, en un suburbio de la capital argentina, de clase media y de marcada cultura católica. Así, permite apreciar cómo los destinos individuales son atravesados por las tensiones y conflictos del periodo. Varias opciones se reconfiguran desde lo histórico y la rememoración: la Iglesia católica de los pobres, la militancia juvenil en el peronismo o las organizaciones armadas revolucionarias antes del golpe de 1976. Si bien en la novela prevalece la narración en tercera persona, es marcada la perspectiva interna de Frik. Esto se vuelve patente en el último capítulo "Casandra Frik habla con los muertos", parte teatral de la novela donde la protagonista, desde su presente adulto, habla con algunos de aquellos espectros del pasado. ${ }^{3}$ Subrayamos este fragmento porque el peso de las ausencias es realmente relevante en el género narrativo histórico - de allí la importancia de la restitución por el lenguaje - y se vuelve acuciante, constitutivo en términos mentales y afectivos, para el género de la narrativa de memoria, tanto ficcional como testimonial. La literatura 
histórica y las narrativas de la memoria son, por excelencia, discursos de las ausencias.

Por su parte, la narrativa de María Teresa Andruetto puede, en su conjunto, ser también leída como un repertorio de géneros de la memoria. Desde la importancia de la reconstrucción oral hasta los usos de informes, registros documentales, testimonios y diversos tipos de archivos, aquellas formas genéricas aparecen como generadoras de las historias contadas y como elementos que permiten recomponer, desde cada versión, las identidades y sus trayectorias vitales e históricas. Por el dinamismo de la ficción, podemos apreciar, asimismo, el camino de narrar cada identidad en esa recomposición memorística, en tanto proceso de identificación, tal como lo entiende Derrida: “Une identité n'est jamais donnée, reçue ou atteinte, non, seul s'endure le processus interminable, indéfiniment phantasmatique, de l'identification" (53). Esto puede ser leído, reflexionado, desde una obra como la de Andruetto, donde de modos diversos, contrapuestos y paradójicos, se exploran memorias, problematizando los instrumentos, los materiales y el lenguaje que las conforman. Tal es el caso de los cuentos y novelas de la autora, como Tama (1992), La mujer en cuestión (2002), Lengua madre (2010) y Los manchados (2015). Con Lengua madre elegimos culminar estas reflexiones. En ella, Julieta, joven argentina nacida en 1977 que en el presente hace su doctorado en letras en Alemania, vuelve a su país tras la muerte de su madre. Y es entonces cuando una caja con cartas y fotos que esta le ha dejado, desencadena la puesta en relato de las verdades vitales de su familia, desde la historia cotidiana de la Argentina, entre los 70 y el presente. En esa caja, en sus testimonios y memorias circulantes y en este novedoso trabajo desde la ficción se cifran las interacciones contemporáneas entre historia, memoria y literatura, que implican no solo al espacio literario sino también a la sociedad y las culturas que la enmarcan.

Universidad Nacional de Córdoba - IDH, CONICET

NOTAS

1 Marcelo Maggi en sus cartas insiste en no perder la "mirada histórica" para no quedar paralizados y escépticos ante el presente más inmediato del mundo narrado, que es la dictadura iniciada en 1976 en Argentina - el pasadopresente más inmediato narrado en Respiración artificial corresponde al periodo 1976-1979 (Piglia 20). 
2 Se reconstruye aquí desde el lenguaje una época de la fábula contada que podría datarse entre alrededor de 1573 hasta llegar a casi cien años después.

3 Lo teatral es capital en la narración: es leitmotiv y elemento estructurador de la fábula, ya que en torno a una puesta teatral escolar de Todos éramos hijos de Arthur Miller gira en gran medida la rememoración de la historia

OBRAS CITADAS

Andruetto, maría teresa. Lengua madre. Buenos Aires: Mondadori, 20 ro.

-. "La escena en el cuento" y "Literatura y memoria". La lectura, otra revolución. Buenos Aires: Fondo de Cultura Económica, 2015.

—. La mujer en cuestión. Córdoba: Alción, 2003.

—. Los manchados. Buenos Aires: Literatura Random House, 2015.

-. Tama. Córdoba: Alción, 2003.

AR F UCH, LEON OR. Memoria y autobiografía. Buenos Aires: Fondo de Cultura Económica, 20I3.

CAPAR Rós, ma RTín. Ansay o los infortunios de la gloria. Buenos Aires: Ada Korn, I984.

Demit Ró pul os, Liber ta D. Río de las congojas. Pról. Ricardo Piglia. Buenos Aires: Fondo de Cultura Económica, 2014.

DER R D A, JA CQUES. Le monolinguisme de l'autre, o le prothésis de le origin. Paris: Galilée, 1996.

DRUCAROFF, ELSA. "El trauma del pasado reciente". Los prisioneros de la torre. Política, relatos y jóvenes en la posdictadura. Buenos Aires: Emecé, 201I. 293330.

—. "Hijos y padres: el imaginario filicida de la posdictadura". Los prisioneros de la torre. Política, relatos y jóvenes en la posdictadura. Buenos Aires: Emecé, 20 II. $33 \mathbf{I}^{-} 378$.

—. "Transmisión quebrada de la experiencia histórica". Los prisioneros de la torre. Política, relatos y jóvenes en la posdictadura. Buenos Aires: Emecé, 2011. 3794I5.

Fe ie RS Tein, DAniel. Memorias y representaciones. Sobre la elaboración del genocidio. Buenos Aires: Fondo de Cultura Económica, 2012.

F O GWILL, ROD OLF O. Los pichiciegos. Buenos Aires: El Ateneo, 2010.

Gat ti, Ga B R E L. Identidades desaparecidas. Peleas por el sentido en los mundos de la desaparición forzada. Buenos Aires: Prometeo, $201 \mathrm{I}$.

Lo J 0, MARía RoSA. Todos éramos hijos. Buenos Aires: Sudamericana, 2014.

—. "La novela histórica desde I980: próceres con cuerpo, heroínas en el espacio público". Identidad y narración en carne viva. Cuerpo, género y espacio en la novela argentina (1980-2010). Eds. María Rosa Lojo y María Laura Pérez Gras. 
Dir. María Rosa Lojo y Michele Soriano. Buenos Aires: Universidad del

Salvador, 2010. 161-208.

Lud mer, jos e f ina. Aquí América Latina. Una especulación. Buenos Aires: Eterna

Cadencia, 2010.

martínez, tomás eloy. La novela de Perón. Buenos Aires: Planeta, 1991.

MER CA DER, MARTHA. Juanamanuela, mucha mujer. Barcelona: Planeta, 1983.

miguel, maría esther DE. La amante del Restaurador. Buenos Aires: Planeta,

1993.

Nunca más. Informe de la Comisión Nacional sobre la Desaparición de Personas.

Buenos Aires: Eudeba, 2005.

PAS O, FE R N AN D O D L. Noticias del Imperio. México: Diana, 1987.

PI G LIA, RI CA R D . Respiración artificial. Buenos Aires: Sudamericana, 1988.

-. Tres propuestas para el próximo milenio (y cinco dificultades). Buenos Aires:

Fondo de Cultura Económica, 2001.

PONS, MARÍA CRISTINA. Memorias del olvido. La novela histórica de fines del siglo

XX. México: Siglo XXI, 1996.

PoSSE, A B E L. Los perros del paraíso. Buenos Aires: Emecé, 1987.

Ricoeur, PAul. La memoria, la historia, el olvido. Trad. Agustín Neira. Buenos

Aires: Fondo de Cultura Económica, 2000.

—. Historia y narratividad. Trad. Gabriel Aranzueque Sahuquillo. Barcelona: Paidós, 1999.

Rivera, And És. En esta dulce tierra. Buenos Aires: Alfaguara, 1995.

—. La revolución es un sueño eterno. Buenos Aires: Grupo Editor Latinoamericano, 1987.

Ro A B AStos, Aug usto. Yo el Supremo. Buenos Aires: Siglo XXI, 1974.

SAER, JUAN JoSÉ. El entenado. Buenos Aires: Alianza, 1992.

SARACENI, GINA A LESSANDRA. Escribir hacia atrás: herencia, lengua, memoria.

Buenos Aires: Beatriz Viterbo Editora, 2008.

Vezzet t I, hu go. Guerra, dictadura y sociedad en la Argentina. Buenos Aires: Siglo

$\mathrm{XXI}, 2003$.

villani, mario y fernando reati. Desaparecido. Memorias de un cautiverio. Club

Atlético. El Banco. El Olimpo. Pozo de Quilmes y ESMA. Buenos Aires: Biblios,

2011.

VIÑAS, DAvid. Cuerpo a cuerpo. México: Siglo XXI, 1979.

WAlsh, Ro do l F o. Operación masacre. Buenos Aires: Planeta, 1994.

—. ¿Quién mató a Rosendo? Buenos Aires: Ediciones Tiempo Contemporáneo, 1969. WhIT E, HA Y DE . Metahistoria. La imaginación histórica en la Europa del siglo XIX.

Trad. Stella Mastrangelo. México: Fondo de Cultura Económica, 1992. 